\title{
Web Tabanlı Seyahat Aracılarını Kullanan Akademik Personelin Elektronik Hizmet Kalitesi, Memnuniyet Ve Sadakat İlişkisinin İncelenmesi
}

\author{
An Investigation of Relationship Between Perceived \\ Electronic Service Quality, Satisfaction and Loyalty For Academic Personal \\ Using Web Based Travel Intermediaries
}

\author{
Sercan YILDIZ \\ İstanbul Üniversitesi \\ Sosyal Bilimler Enstitüsü \\ E-posta:srcn_yldz@hotmail.com
}

Prof. Dr. Beykan çizEL

Akdeniz Üniversitesi

Turizm Fakültesi

E-posta: beykan@akdeniz.edu.tr

\section{Öz}

Bu çalışmada, web tabanlı seyahat aracılarını kullanan akademik personelin algılanan elektronik hizmet kalitesi, memnuniyet ve sadakat ilişkisi incelenmiştir. Akdeniz Üniversitesi'nde görev yapmakta olan ve web tabanlı seyahat aracılarını, en az bir defa kullanma deneyimine sahip olan 300 akademik personelden, anket tekniği ile veriler toplanmış, araştırmanın amacına uygun istatistiksel analiz yöntemleri ile incelenmiş ve değerlendirilmiştir. Araştırma sonuçları, sözü edilen üç değişken arasındaki ilişkinin varlığını sayısal olarak ortaya koymaktadır. Bunun yanında, elektronik hizmet kalitesini oluşturan her bir boyutun, müşteri memnuniyetini ve sadakatini farklı önem derecelerinde yordama gücünün olduğunu göstermektedir. Bulgular web tabanlı seyahat aracıları yöneticilerinin müşteri memnuniyetini ve müşteri sadakatini sağlamak için hangi faktörlere öncelik vermesi gerektiği hususunda önemli bilgiler sunmaktadır.

Anahtar Sözcükler: Web tabanlı seyahat aracıları, Elektronik hizmet kalitesi, Memnuniyet, Sadakat

\begin{abstract}
This study examines the relationship between factors influencing the e-service quality of web based travel intermediaries and customer satisfaction and loyalty. For the purpose of the study, data was collected using survey method from 300 faculty members working at Akdeniz University and have purchase experience from web based travel intermediaries at least once. The study employed regression analysis. Study findings were discussed, evaluated and interpreted with the support of related literature. Statistical analysis reveals the existence of a relationship between three variables mentioned above. Besides, the results suggest that electronic service quality dimensions have varying severity of predictive power on customer satisfaction and loyalty. Study findings reveal valuable information for the managers of web based travel intermediaries about the electronic service quality dimensions that influence customer satisfaction and customer loyalty.
\end{abstract}

Keywords: Web based travel intermediaries, Electronic service quality, Satisfaction, Loyalty 


\section{Giriş}

İletişim ve enformasyon teknolojilerindeki gelişmeler, turizm endüstrisinde farklı niteliklere sahip dağıtım kanallarının ortaya çıkmasına yol açmaktadır. Bu sebeple, hizmet endüstrisinin genelinde olduğu gibi internet, turizm endüstrisinde de önemli bir iş ve satış platformu konumuna gelmiştir (Buhalis, 2003). Web tabanlı seyahat aracılarının pazardaki başarısı, sundukları elektronik hizmetin (e-hizmet) kalitesi ile doğru orantılıdır. E-hizmet, müşteri hizmetlerini güçlendirmeyi amaç edinmiş, hizmet sağlayıcıları tarafından sağlanan sistemlerin ve teknolojilerin destekleri ile birleştirilmiş, müşteriler tarafından internet üzerinden kullanılan etkileşimli hizmet olarak tanımlanabilir (Ruyter ve diğ., 2001; Şenel ve diğ., 2012). Oliveira ve diğ. (2002) göre e-hizmet, gelişmiş iletişim ve enformasyon teknolojileri yardımıyla, internet üzerinden sağlanan etkileşimli hizmetlerden oluşmaktadır. Geleneksel hizmet kalitesi, bir işletmenin mükemmellik ve üstünlüğü ile tüketicilerde yarattığı etki iken e-hizmet kalitesi, bir internet sitesinin etkin ve verimli bir şekilde alışveriş sürecinde ve alışveriş sonrasında, teslimatın gerçekleşmesi ile oluşan etkiyi temsil etmektedir (Bressolles ve diğ., 2014). E-hizmet kalitesi, elektronik ticaretin (e-ticaret) birçok yönü üzerinde önemli etkiye sahiptir. Bunlar site öz kaynakları, siteye yönelik tüketici tutumları, elektronik alışverişe (e-alışveriş) karşı tutumlar, ürünlerin ve hizmetlerin algılanan değerleri, daha fazla alışveriş isteği, çevrimiçi kullanıcı memnuniyeti, sadakat ve çapraz satın almadır (Ladhari, 2010).

E-hizmet sektörü bağlamında memnuniyet, hizmet sağlayıcılar ile gerçekleştirilen işlemler ya da gerçekleşen iyi ilişkiler sonucunda algılanan değerdir. Buradan hareketle, hizmet sağlayıcıları tarafından algılanan memnuniyet dereceleri, tüketicilerin kendi değer yargılarının bir sonucudur. Elde edilen memnuniyet derecesi, tüketicilerin genel duygularını da yansıtmaktadır (Luo ve Lee, 2011). Bu sebeple, çevrimiçi ortamda faaliyet gösteren işletmelerin önem vermesi gereken en önemli konulardan bir tanesi de "memnuniyet" olmalıdır. Bu noktada bir çok araştırma, web sayfalarının e-hizmet kalitesinin, müşteri memnuniyeti yaratmada öncül olduğunu vurgulamaktadır (Oliver, 1980; Ho ve Lee, 2007; Huang ve Dubinsky, 2014). E-hizmet kalitesinin müşteri memnuniyeti ve müşteri sadakati ile ilişkisi de, sıklıkla tartışılan bir konudur (Churchill, 1979; Oliver, 1980; Parasuraman ve diğ., 1988; Ho ve Lee, 2007; Tsang ve diğ., 2010; Özdemir ve diğ., 2012; Cheng ve Rashid, 2013). İlgili alanyazında, web sayfalarına duyulan sadakat kavramı, tüketicilerin tercihi olarak, belirli siteleri sık sık ziyaret etmek ve o sitelerde alışveriş deneyiminde bulunmak olarak tanımlanmaktadır (Pearson ve diğ., 2012). Müşteri memnuniyetinin işletmelere sağladığı en büyük faydalardan biri, mevcut müşterileri elde tutmak olduğu bilindiği üzere, birçok araştırmacı çalışmalarını tatmin olmuş müşteri üzerine, özellikle de müşteri memnuniyeti ve müşteri sadakati arasındaki bağlantıya odaklamaktadır (Özdemir ve diğ., 2012; Cheng ve Rashid, 2013). Bu çalışmanın temel amacı ise, web tabanlı seyahat aracılarının e-hizmet kalitesini etkileyen her bir boyutun, müşteri memnuniyeti ve müşteri sadakati üzerindeki önem derecelerinin incelenmesidir. Araştırma bulguları, ilgili alanyazın desteği ile tartışılmış, değerlendirilmiş ve yorumlanmıştır. Bulguların araştırmacı ve uygulamacılar için önemli ipuçları verebileceği düşünülmektedir.

\section{Literatür Taraması}

Teknolojik gelişmelere paralel olarak ortaya çıkan elektronik turizm (e-turizm) kavramı, turizm endüstrisindeki tüm iş süreçlerinin, değer zincirinin ve hatta ürün ve hizmetin kendisinin dijital ortama taşınmasını ifade etmektedir. İletişim ve enformasyon sistemlerindeki gelişmelere paralel olarak artan e-ticaret imkânları, tüm endüstrilerde 
olduğu gibi turizm endüstrisinde de devrim niteliğinde değişikliklere yol açmıştır (Buhalis, 2003). Öyle ki, turizm endüstrisinde yer alan geleneksel dağıtım kanallarının yanında, küresel dijital dağıtım kanallarını kullanan web tabanlı seyahat aracılarının (Tripadvisor.com, Expedia.com, Booking.com vb.) sayısı her geçen gün artmaktadır. Enformasyon teknolojilerindeki hızlı gelişim ve ilerleme ile birlikte artan e-ticaret hacmi, pazarlamanın hizmet kalitesi ve hizmet memnuniyeti gibi geleneksel bazı kavramlarının, araştırmacılar tarafından yeniden değerlendirilmesine yol açmıştır.

E-hizmet, hizmet elemanlarının doğrudan müdahalesi olmaksızın hizmet müşterilerinin, ilgili hizmet firmalarının teknolojik altyapılarıyla desteklediği web siteleriyle karşılıklı etkileşime girerek gerçekleştirdiği bir self-servis hizmet sürecidir (Çelik ve Başaran, 2008). E-ticaret üzerine yapılan araştırmalar, e-hizmet kalitesinin, işletme başarı ve başarısızlığını etkileyen en önemli faktör olduğunu göstermiştir (Santos, 2003). Elbette, kaliteli hizmet kavramı, işletmelerin müşteri çekebilmeleri için önemli bir faktördür. Ayrıca, e-hizmet kalitesi, dijital dünyada uzun süreli avantaj sağlamanın anahtarı durumundadır. Bu noktada, web sitelerine ilişkin e-hizmet kalitesi, web sitelerinin satın alma sürecini nasıl etkin ve verimli bir hale getirdiği ve ürün ve hizmet sunumunun hangi ölçüde kolaylaştırdığı ile ilgilidir. Buradan hareketle, web sitelerine ilişkin e-hizmet kalitesi, web sitelerinin etkileşimi, verimliliği ve sistem kullanılabilirliği gibi servis yönlerini kapsamaktadır (Shu-Fang ve Tzai-Zang, 2011).

Bir işletmenin, uzun yıllar ayakta kalabilmesi ve faaliyetlerini devam ettirebilmesi için gerekli olan, en önemli özelliklerinden biri, müşteri memnuniyeti yaratabilmesidir. İşletmeler açısından memnuniyeti, tüketicilerin işletme hizmetlerinden ve satın alma deneyiminden elde ettiği sonuç olarak tanımlamak mümkündür (Papaioannou ve diğ., 2013). Başka bir tanıma göre memnuniyet, bir şirket ile başka bir şirket arasındaki ilişkinin bütün yönleri ile değerlendirilmesi sonucunda tüketicilerde ortaya çıkan işletmelere yönelik olumlu duygusal durumdur. Bu bağlamda memnuniyet, beklentiler ile ortaya çıkan arasındaki ilişkidir (Chang ve diğ., 2012). Tüketicilerin tutumları, arzuları, istekleri, işletmelerden elde ettikleri mal veya hizmet satın alma kalitesi, tüketiciler üzerinde farklı derecelerde memnuniyet algıları oluşturmaktadır (Papaioannou ve diğ., 2013). Basit bir şekilde, beklentileri karşılayan ya da aşan bir hizmet kalitesi ile karşılaşıldığında, algılanan memnuniyet yüksek derecede olmaktadır. En nihayetinde bu durum, memnun müşteriler ortaya çıkarmaktadır. Web sayfalarının hizmet kalitesi, kullanıcıların genel memnuniyeti açısından da önemlidir. Örneğin Tsang ve diğ. (2010), Hong Kong'da faaliyet gösteren web tabanlı seyahat aracılarının sistemlerine yönelik olarak yaptıkları çalışma ile, algılanan e-hizmet kalitesini etkileyen hangi boyutların müşteri memnuniyeti yaratılması açısından daha önemli olduğunu araştırmıştır.

Sadakat kavramı çeşitli şekillerde tanımlanabilir ve kavramsallaştırılabilir. Web sayfalarına duyulan sadakat kavramını, tüketicilerin tercihi olarak, belirli siteleri sık sık ziyaret etmek ve o sitelerde alışveriş deneyiminde bulunmak olarak tanımlamak mümkündür (Pearson ve diğ., 2012). İlgili alanyazında sadakati kavramsallaştırma adına iki yaygın görüş hakimdir. Birinci görüş, sadakati sadece davranışsal açıdan ele almaktadır. Bu görüşe göre sadakatin tek ve en önemli olumlu etkisi, tekrar satın alma eylemi gösterecek tüketiciler ortaya çıkarmaktır. Bu yaklaşıma bir alternatif olarak Kim ve diğ. (2006) savunduğu görüşe göre sadakat, aynı zamanda duygusal bir kavramdır. $\mathrm{Bu}$ görüşe göre sadakat, psikolojik durum, tutumlar, iltimas duygusu, niyet vb. birçok şey üzerinde olumlu etkiye sahiptir (Marimon ve diğ., 2012). Sadakat kavramı, web tabanlı işletmelerin tasarımı, sunduğu gizliliği, güveni ve memnuniyeti ile ilgili yapılan çalışmalarda da önemli bir değişken olarak görülmektedir. Örneğin Flavian ve diğ. (2006), tüketiciler açısından sadakat yaratan faktörleri ortaya çıkarmak için çalışma 
yapmıştır. Ortaya çıkan sonuçlara göre, kullanıcılar açısından web sitelerinin kullanışlı olması, tüketici sadakati yaratmak açısından önemli bir faktör olduğu görülmüştür. Yang ve diğ. (2009), çevrimiçi oyun siteleri kullanıcıları ile web sitelerinin memnuniyetini ve sadakatini ölçmek için bir çalışma yapmıştır. Bu çalışma ile, "işlem kalitesi", "ücretler" ve "genel hizmet kalitesi", müşteri sadakati yaratılması açısından önemli faktörler olarak dikkat çekmiştir. Yapılan tüm bu çalışmalar ile, web sitelerinin ehizmet kalitesi boyutlarının, algılanan sadakat üzerinde etkili olduğu sonucu ortaya çıkmaktadır.

E-ticaretin gelişimi ile birlikte, tüketicilerin karar verme süreçleri içerisinde internetin öneminin sistematik bir şekilde artması, araştırmacıların e-hizmet kalitesi içerisinde müşteri memnuniyeti ve müşteri sadakati konularını daha fazla irdelemelerine yol açmıştır (Bressolles ve diğ., 2014). İşletmeler, iş dünyasının hangi kulvarında faaliyet gösterirse göstersin, hayatta kalabilmek ve mücadele edebilmek için müşteri memnuniyetini ve müşteri sadakatini sağlamak zorundadır (Osman ve Sentosa, 2013). Memnun edilmiş müşterilere sahip olan bir işletmenin, rakipleri ile rekabet edebilmesi daha kolaydır. Bir mal veya hizmetle ilgili beklentileri karşılanmış bir müşterinin, işletmede tutulması ve tekrar mal veya hizmet satın almasının sağlanması, diğer kişilerin işletmeden mal ya da hizmet satın almasından çok daha kolay olacaktır. Bu bağlamda sadık müşteriler, işletmeyle bütünleşmiş ve işletmeyle aralarında duygusal bağ oluşmuş müşterilerdir (Avcıkurt ve Köroğlu, 2006; Çatı ve Koçoğlu, 2008).

Müşteri sadakatinde, müşteri memnuniyetinin rolü, ilgili alanyazında her zaman anahtar faktör ve temel belirleyici olarak verilmektedir; ancak bu iki kavram birbiri ile karıştırılmamalıdır (Castaneda, 2011). Castaneda'ya (2011) göre, müşteri memnuniyeti ve müşteri sadakati arasındaki ilişkinin ortaya çıkarılması ile ilgili yapılan çalışmaların bir çoğunda, iki değişken arasında, doğrudan veya dolaylı olarak bir ilişki bulunmaktadır. Alanyazında yapılan daha önceki çalışmalar, müşteri sadakati yaratılması açısından memnuniyeti, bir aracı değişken olarak ele almaktadır. Bir başka ifadeyle web tabanlı seyahat aracılarının sistemine duyulan memnuniyet, ilgili sisteme duyulan sadakati de etkilemektedir. İlgili alanyazın taramasından elde edilen bilgiler ışığında aşağıdaki araştırma hipotezleri sınanmıştır:

H1: Elektronik hizmet kalitesi ile müşteri memnuniyeti arasında pozitif yönlü bir ilişki vardır.

H2: Elektronik hizmet kalitesi ile müşteri sadakati arasında pozitif yönlü bir ilişki vardır.

H3: Müşteri memnuniyeti ve müşteri sadakati arasında pozitif yönlü bir ilişki vardır.

Çalışma kapsamında, öncelikle sözü edilen üç değişken arasındaki ilişkinin varlığına yönelik kanıt aranmış ve daha sonra hizmet kalitesinin alt boyutları ile memnuniyet ve sadakat arasındaki ilişkiler ayrıntılı olarak incelenmiştir.

\section{Araştırmanın Yöntemi}

Bu çalışma kapsamında, web tabanlı seyahat aracılarının algılanan e-hizmet kalitesi, memnuniyet ve sadakat ilişkisi incelenmiştir. Bu amaç ile Akdeniz Üniversitesi'nde görev yapmakta olan ve web tabanlı seyahat aracılarını (Expedia.com, Booking.com, Tripadvisor.com, Hotels.com, Tatilsepeti.com vb.) en az bir defa kullanma deneyimine sahip olan 300 akademik personelden, bire bir anket tekniği ile veriler toplanmıştır. Öncelikle, ölçeklerin güvenilirlik ve geçerlilikleri test edilmiştir. Sonrasında araştırmanın 
amacına yönelik olarak geliştirilen hipotezler sınanmıştır. Verilerin analizi ve hipotez testleri için "SPSS for Windows 20" paket programı ve "Lisrel 8.80" paket programı kullanılmıştır. Araştırmada kullanılan anket, iki bölümden oluşmaktadır. İlk bölümde, ankete katılan katılımcılara yönelik demografik sorular yer almaktadır. İkinci bölümde, araştırmanın hipotezlerine yönelik olarak verilen, üç adet ölçek yer almaktadır. Ehizmet kalitesi ölçeği olarak, temelini E-TailQ modelinin oluşturduğu, Tsang ve diğ. (2010) tarafından geliştirilen ölçek kullanılmıştır. Katılımcıların memnuniyet ve sadakat algılarını ölçmek için ise, Ho ve Lee (2007) tarafından geliştirilmiş ve uluslararası yazında geçerliliği ve güvenilirliği test edilmiş ölçekler kullanılmıştır. Tüm ölçüm araçlarında, beş maddeli Likert tipi (1-Kesinlikle Katılmıyorum, 2-Katılmıyorum, 3-Ne Katılıyorum $\mathrm{Ne}$ Katılmıyorum, 4-Katılıyorum ve 5-Kesinlikle Katılıyorum) ölçek kullanılmıştır.

Araştırmanın hipotezlerini test etmek için kullanılan örneklem, Akdeniz Üniversitesinden seçilmiştir. Akdeniz Üniversitesinin toplam öğretim elemanı sayısı 5 Şubat 2015 tarihi itibariyle 1200 kişidir. Bu sayı üzerinden örneklem sayısı $n=N t^{2} p q^{2} / d^{2}(N-1)+t^{2} p q$ formülü ile 291 kişi olarak hesaplanmıştır (Büyüköztürk, 2011). Araştırmaya katılacak kişiler olasılıklı örnekleme türlerinden tabakalı örnekleme yöntemi kullanılarak belirlenmiştir. Her tabakadan bağımsız olarak, rasgele örneklemeyle tabakanın büyüklüğüyle orantılı olarak örneklem seçilmiştir. Buradaki temel amaç, web tabanlı seyahat aracılarını kullanan ve farklı akademik unvanda çalışan akademik personelin, araştırmaya dâhil edilmesini sağlamaktır. Anketler sonucu toplanan veriler analize hazır hale getirilmiştir. Veri setindeki eksik verilerin yerine serilerin ortalamaları yerleştirilmiştir. Ayrıca, verilerin normal dağılıma uygunluğunu test etmek için Kolmogorov Smirnov Testi kullanılmış, her bir değişken için test değerleri ve anlamlılık değerlerinde bir sorun olmadığı görülmüştür. Bunun yanında veri setinde uç/aykırı değerler olup olmadığı incelenerek uç/aykırı değerlerin bulunmadığı gözlenmiş ve analizler 300 kişi üzerinde gerçekleştirilmiştir.

\section{1. Ölçeklerin Geçerlilik ve Güvenilirlik Analizleri}

Veri analiz sürecinin ilk aşamasında ölçeklerin saflaştırıması, geçerliliği ve güvenilirliği için analizler yapılmıştır. Araştırmada ölçeklerin güvenirliğini göstermek için ilk olarak, iç tutarlılık yöntemi kullanılmıştır. SPSS programı yardımıyla yapılan güvenilirlik analizi sürecinde ölçeklerin iç tutarlılığını düşüren ve ifade-boyut (item to total) korelâsyonu ve/veya faktör yükleri düşük olan ifadeler, ölçeklerden çıkarılmıştır. Bunun nedeni, düşük faktör yüküne ve düşük ifade-boyut korelâsyonuna sahip ifadelerin, ilgili kavramı ölçme olasılığının oldukça düşük olmasıdır (Özdamar, 2004). Sonrasında tüm ölçekler için açımlayıcı faktör analizi yapılmıştır.

Güvenilirlik için yapılan ilk analiz faktör analizidir. E-hizmet kalitesi ölçeğine ait faktör analizi sonuçları göre her boyuta ait ifadelerin faktör yükleri, Cronbach's Alpha değerleri ve her bir faktörün varyansı açıklama oranları Tablo 1'de gösterilmiştir. Elde edilen bu altı faktörün toplam varyansı açıklama oranı \% 67,191 olarak bulunmuş olup, kabul edilebilir düzeydedir (Nakip, 2003). Faktörlerin içsel tutarlılıkları için hesaplanan Cronbach's Alpha değerleri 0,730 ile 0,918 değerleri arasında değişmekte olup, ölçeğin güvenilir olduğunu göstermektedir (Hair ve diğ., 1998). 
Tablo 1: E-Hizmet Öıçeği Açımlayıcı Faktör Analizi ve Güvenirlik Katsayıları

\begin{tabular}{|c|c|c|c|}
\hline Boyutlar & Ölçek İfadeleri & $\begin{array}{l}\text { Faktör } \\
\text { Yükü }\end{array}$ & $\begin{array}{l}\text { Toplam } \\
\text { Varyansı } \\
\text { Açıklama } \\
\text { Oranı } \\
\end{array}$ \\
\hline $\begin{array}{l}\text { Emniyet ve } \\
\text { Güvenlik }\end{array}$ & $\begin{array}{l}\text { Çevrimiçi seyahat aracılarını kullanırken, kendimi sistem } \\
\text { tarafından korunuyor hissederim. }\end{array}$ & ,860 & $\% 14,65$ \\
\hline$\alpha=0,918$ & $\begin{array}{l}\text { Bilgilerimi iznim dışında diğer siteler ile paylaşmayacağı } \\
\text { konusunda çevrimiçi seyahat aracılarına güvenirim. }\end{array}$ & ,857 & \\
\hline & $\begin{array}{l}\text { Çevrimiçi seyahat aracılarına bilgilerimi kötüye } \\
\text { kullanmayacağına konusunda güvenirim. }\end{array}$ & ,807 & \\
\hline & $\begin{array}{l}\text { Çevrimiçi seyahat aracılarından işlem yaparken (ödeme, } \\
\text { rezervasyon vb.) kendimi güvende hissederim. }\end{array}$ & ,806 & \\
\hline & $\begin{array}{l}\text { Çevrimiçi seyahat aracıları, yeterli güvenlik önlemlerine } \\
\text { sahiptir. }\end{array}$ &, 804 & \\
\hline \multirow{2}{*}{$\begin{array}{l}\text { İsteklerin Yerine } \\
\text { Getirilmesi ve } \\
\text { Duyarlılık }\end{array}$} & Sorduğum sorular anında cevaplanır. & ,754 & $\% 14,38$ \\
\hline & $\begin{array}{l}\text { Çevrimiçi seyahat aracıları müşteri istek ve ihtiyaçlarına } \\
\text { yanıt vermeye hazır ve isteklidir. }\end{array}$ & ,744 & \\
\hline$\alpha=0,896$ & $\begin{array}{l}\text { Çevrimiçi seyahat aracıları müşteri hizmetleri personeli } \\
\text { bana yardım etmeye her zaman hazırdır. }\end{array}$ & ,713 & \\
\hline & $\begin{array}{l}\text { Sorun yaşadığım zaman, çevrimiçi seyahat aracıları } \\
\text { çözüm için benimle samimiyetle ilgilenmektedirler. }\end{array}$ & 679 & \\
\hline & $\begin{array}{l}\text { Çevrimiçi seyahat aracılarından yapmış olduğum } \\
\text { rezervasyondaki istek ve taleplere tam olarak uyulur. }\end{array}$ &, 660 & \\
\hline & $\begin{array}{l}\text { Çevrimiçi seyahat aracıları rezervasyonları doğru şekilde } \\
\text { yapar. }\end{array}$ & 657 & \\
\hline $\begin{array}{l}\text { Enformasyon } \\
\text { Kalitesi ve İçerik }\end{array}$ & Çevrimiçi seyahat aracıları derinlemesine bilgi sağlar. & ,691 & $\% 10,52$ \\
\hline$\alpha=0,804$ & Çevrimiçi seyahat aracıları güncel bilgi sağlar. & ,689 & \\
\hline & $\begin{array}{l}\text { Çevrimiçi seyahat aracıları ürün ve hizmetler hakkında } \\
\text { doğru ve net bilgi sağlar. }\end{array}$ &, 680 & \\
\hline & Çevrimiçi seyahat aracıları bilgi için iyi bir kaynaktır. & 672 & \\
\hline & $\begin{array}{l}\text { Çevrimiçi seyahat aracılarından aldığım bilgi, geleneksel } \\
\text { işletmelerden alacağım bilgi ile aynı kalitededir. }\end{array}$ &, 538 & \\
\hline $\begin{array}{l}\text { Görünüş ve } \\
\text { Sunum }\end{array}$ & $\begin{array}{l}\text { Çevrimiçi seyahat aracıları sistemde düzgün renkler } \\
\text { kullanır. }\end{array}$ & ,788 & $\% 10,21$ \\
\hline$\alpha=0,848$ & $\begin{array}{l}\text { Çevrimiçi seyahat aracıları sisteminin içeriğinde } \\
\text { kullanılan yazı tipleri uygundur. }\end{array}$ & ,749 & \\
\hline & $\begin{array}{l}\text { Çevrimiçi seyahat aracılarının sistemi düzenli } \\
\text { gözükmektedir. }\end{array}$ & ,719 & \\
\hline & $\begin{array}{l}\text { Çevrimiçi seyahat aracıları sistemde düzgün multimedya } \\
\text { içeriği kullanır. }\end{array}$ & ,705 & \\
\hline $\begin{array}{l}\text { Web Site } \\
\text { İşlevselliği }\end{array}$ & Çevrimiçi seyahat aracıları zaman kaybına yol açmaz. & ,759 & $\% 9,008$ \\
\hline$\alpha=0,730$ & $\begin{array}{l}\text { Çevrimiçi seyahat aracılarından işlem yapmak kolay ve } \\
\text { hızlıdır. }\end{array}$ & ,719 & \\
\hline & Sistemde bulunan arama özelliği faydalıdır. &, 619 & \\
\hline Müşteri İlişkileri & $\begin{array}{l}\text { Çevrimiçi seyahat aracılarından rezervasyon yapmak } \\
\text { veya iptal etmek kolaydır. }\end{array}$ & ,722 & $\% 8,419$ \\
\hline$\alpha=0,740$ & $\begin{array}{l}\text { Elde etmek istediğim şeye doğrudan, zahmetsizce } \\
\text { erişebiliyorum. }\end{array}$ &, 592 & \\
\hline & $\begin{array}{l}\text { Çevrimiçi seyahat aracılarının web sitesinde ürün ve } \\
\text { hizmet kategorileri iyi şekilde düzenlenmiştir. }\end{array}$ &, 565 & \\
\hline & $\begin{array}{l}\text { Sistem, seyahat deneyimlerinin paylaşıldığı bir platform } \\
\text { sunmaktadır. }\end{array}$ &, 562 & \\
\hline
\end{tabular}

Toplam Varyans Açıklama Oranı (\%): 67,19, KMO: 0,927, Bartlett Küresellik Testi: 4603,275 p: ,000 
Tablo 2'de memnuniyet ve sadakat ölçeklerine ilişkin güvenilirlik katsayıları ve tek faktör varyans açıklama oranları verilmiştir. Tek faktörlü birer ölçek olan memnuniyet ve sadakat ölçeklerinin iç tutarlık değeri olan Cronbach's Alpha değerlerinin 0,875 ve 0,887 olduğu görülmektedir. Bu değerler, ölçeklerin gayet güvenilir olduğunun göstergesidir. Tek faktörlü ölçeklerde açıklanan varyans \%30 ve daha fazla olması yeterli görülebilir (Büyüköztürk 2011). Memnuniyet ölçeğinin tek faktör varyans açıklama oranı \%73,184 olarak ve sadakat ölçeğinin tek faktör varyans açıklama oranı ise $\% 75,137$ olarak ölçülmüştür.

Tablo 2: Memnuniyet ve Sadakat Ölçeği Güvenirlik Katsayıları

\begin{tabular}{|l|l|l|l|l|}
\hline \multicolumn{2}{|l|}{ Ölçekler } & Ölçek İfadeleri & Faktör Yükü & $\begin{array}{l}\text { Varyansı } \\
\text { Açıklama Oranı }\end{array}$ \\
\hline \multicolumn{2}{|l|}{ Memnuniyet Ölçeği } & Sistemi tekrar kullanmak isterim. & 0,884 & $\% 73,184$ \\
\hline$\alpha=0,875$ & & $\begin{array}{l}\text { Sistemden yapmış olduğum en son satın alma, } \\
\text { doğru bir karardı }\end{array}$ & 0,863 & \\
\hline & & $\begin{array}{l}\text { Sistemden alışveriş yapmaktan gerçekten zevk } \\
\text { aldım. }\end{array}$ & 0,850 & \\
\hline & $\begin{array}{l}\text { Sistemden alışveriş yapmak gerçekten akıllıca bir } \\
\text { karardı. }\end{array}$ & 0,824 & \\
\hline Sadakat Ölçeği & $\begin{array}{l}\text { Sistem hakkındaki olumlu düşüncelerimi herkesle } \\
\text { paylaşacağım. }\end{array}$ & 0,917 & $\% 75,137$ \\
\hline$\alpha=0,887$ & $\begin{array}{l}\text { Sistemden yakın zamanda tekrar alışveriş } \\
\text { yapacağım. }\end{array}$ & 0,873 & \\
\hline & & Sistemi tavsiye ederim & 0,843 & \\
\hline & $\begin{array}{l}\text { Gelecekte de turizm ürün ve hizmetini satın alamda } \\
\text { ilk tercihim web tabanlı seyahat aracıları olacaktır. }\end{array}$ & 0,831 & \\
\hline
\end{tabular}

Geçerlilik, testleri, bireyin ölçülmek istenen özelliğini ne derece doğru ölçtüğüyle ilgili bir kavramdır. Açımlayıcı faktör analizinden sonra altı boyut ve 27 maddeden oluşan e-hizmet kalitesi ölçeği, doğrulayıcı faktör analizi ile test edilmiştir. Bu analiz için "Lisrel 8.80" paket programından yararlanılmıştır. Bu amaçla, öncelikle modelin tanımlanması gerekmektedir. Modelin tanımlanması, yapılan analizin kuramsal bir altyapıya dayandırılmasıdır. Bu aşamada, modelin tanımlanmasında e-hizmet kalitesi konusunda geliştirilen kavramsal çerçeveden ve bu çerçeve temel alınarak gerçekleştirilen açımlayıcı faktör analizi sonuçlarından yararlanılmıştır. Bu sonuçlara uygun olarak açımlayıcı faktör analizi aşamasında belirlenen faktör yapıları "Yol Analizi" yönteminden yararlanılarak, ölçme modeli biçiminde tasarlanmıştır. Modele ait faktör ağırlıkları en çok olabilirlik metoduna göre, standardize edilmiş katsayı tahminleri olarak hesaplanmıştır. Bütün katsayılar 0,01 önem derecesinde anlamlı bulunmuştur. Doğrulayıcı faktör analizinde, gözlem değişkenlerinin ait oldukları faktörleri tek başlarına ve tam olarak değil, diğer değişkenlerle birlikte açıkladığı varsayılmakta ve bu nedenle her ilişki için bir hata payı da hesaba katılmaktadır (Schumacker, 2004). Modelin sınanmasında, modelin uyum istatistikleri ve modifikasyon indeksi sonuçları ayrıntılı olarak incelenmiştir. $x 2$ değerinin serbestlik derecesine oranının ikiden küçük olması mükemmel uyumu göstermektedir. E-hizmet kalitesi ölçme modeli için bu değer $X 2 / s d=581.37 / 309=1,88$ olarak hesaplanmıştır. Modele ilişkin diğer uyum iyiliği indeks değerleri $\mathrm{GFI}=0,87 \mathrm{CFI}=0,93 \mathrm{NFI}=0,96 \mathrm{RMSEA}=0,054 \mathrm{AGFI}=0,85 \mathrm{TLI}=0,98$ olarak ölçülmüştür.

Uyum indekslerine ait genel kriterler karşılaştırıldığında, bu çalışmaya ait değerlerin kabul edilebilir ölçüler içerisinde olduğu görülmektedir. Her faktör, kendisini oluşturan soruları doğru biçimde temsil ettiği söylenebilir. Bazı değerlerin, kritik değerlerin çok az altında kalması örneklem boyutuyla veya modelin karmaşıklığıyla da ilişkilendirilebilir. Ancak bu durum ilişkinin yönü açısından bir problem olarak 
görünmemektedir. Sonuç olarak e-hizmet kalitesi ölçme modeline ilişkin uyum indeksleri ve temel parametre tahminleri modelin verilerle uyum içerisinde olduğunu göstermektedir (Hair ve diğ., 1998). 27 maddeye ilişkin ölçeğin fit endeksleri, madde faktör yükleri $(\lambda), t$ değerleri, hata varyansları ve açıklanan varyans oranları $\left(R^{2}\right)$ ile birlikte değerlendirilmiştir. Doğrulayıcı faktör analizine göre verilen faktör yükleri $(\lambda)$, 0,48 ile 0,88 arasında değişmektedir. Bulunan bu faktör yük değerleri 0,10'dan küçükse "küçük etki", 0,30 civarındaysa "orta etki" ve 0,50'den büyükse "büyük etki" olduğunu göstermektedir (Kline, 2005). Ayrıca tüm maddelere ilişkin $t$ değerleri anlamlıdır. Açıklanan varyans değerleri yüksek değerlerdedir. Yapılan doğrulayıcı faktör analizi, ölçeğin son halini 27 madde ve altı alt boyut olarak mümkün kılmaktadır. Tüm sonuçlar bütün olarak sağlandığında, modele dâhil edilen tüm maddelerin, model ile uyumlu olduğu söylenebilir. Bu bulgular, ifadelerin faktörler tarafından doğru açıklandığını ve ölçeğin yapı geçerliliğinin bir kanıtı olarak kabul edilebilir.

Yakınsama geçerliliği, bir yapıyı oluşturan değişkenlerin veya alt boyutların kendi aralarındaki korelasyon katsayılarının yüksek olmasıdır. Başka bir tanıma göre yakınsama geçerliliği aynı kavrama ilişkin bağımsız ölçütlerin yakınlaştığı ya da yüksek korelâsyon gösterdiği durumlardır. Bir ölçeğin yakınsama geçerliliğinden bahsedebilmek için, o ölçeğin yapı geçerliliğinin sağlanması, ölçeği oluşturan her bir boyutun birleşik güvenilirliğinin (Composite Reliability) 0,7'ye yakın ya da yüksek olması beklenmektedir (Hair ve diğ., 1998). Yakınsama geçerliliğinin sağlanması için bir diğer varsayımda, açıklanan ortalama varyans hesabıdır (AOV). Bu varsayıma göre ölçeği oluşturan her bir boyutun açıklanan ortalama varyansı 0,5 veya yüksek olmalıdır (Fornell ve Larcker, 1981). E-hizmet kalitesi ölçeğine ilişkin yakınsama geçerliliği analizi için öncelikle yukarıda belirtilen kriterlere ilişkin uyum değerleri Tablo 3'te gösterilmiştir. Verilen değerlere bakıldığında, bütün faktörler için yapı güvenilirliği katsayıları istenilen seviyede olduğu söylenebilir. Açıklanan ortalama varyans değerlerine bakıldığında, üç boyut dışında kalan tüm boyutlar için istenilen seviyede olduğu söylenebilmektedir. Tablo 3'te verilen hem yapı güvenirliği ve AOV değerleri hem de korelasyon değerleri göz önüne alındığında, e-hizmet kalitesi ölçeğinde yakınsama geçerliliğinin varlığından söz edilebilir.

Tablo 3: Faktörler Arası Korelasyonlar, Yapı Güvenirliği ve AOV Değerleri

\begin{tabular}{|l|l|l|l|l|l|l|l|l|}
\hline & Faktör1 & Faktör2 & Faktör3 & Faktör4 & Faktör5 & Faktör6 & $\begin{array}{l}\text { Yapı } \\
\text { Güvenirliği }\end{array}$ & AOV \\
\hline Faktör1 & - & & & & & & 0,919 & 0,693 \\
\hline Faktör2 &, $452^{* \prime}$ & - & & & & & 0,897 & 0,592 \\
\hline Faktör3 &, $409^{* *}$ &, $627^{* *}$ & - & & & & 0,817 & 0,477 \\
\hline Faktör4 &, $443^{* *}$ &, $532^{* *}$ &, $519^{* *}$ & - & & & 0,852 & 0,591 \\
\hline Faktör5 &, $262^{*}$ &, $526^{*}$ &, $497^{*}$ &, $430^{*}$ & - & & 0,742 & 0,494 \\
\hline Faktör6 &, $385^{* *}$ &, $619^{*}$ &, $558^{*}$ &, $535^{*}$ &, $571^{*}$ & - & 0,764 & 0,454 \\
\hline
\end{tabular}

Ayrışma (Diskriminant) geçerliliği, kavramsal olarak ölçeği oluşturan boyutların birbirinden ayrıması olarak tanımlanabilir (Nunnally, 1978). Diskriminant geçerliliği, farklı yapılar arasındaki ayrışma derecesini göstermektedir. Bu araştırmada ayrışma geçerliliği olarak Fornell ve Larcker'in (1981) önerdiği model kullanılmıştır. Bu modele göre ayrışma geçerliliği, bir yapıya ait açıklanan ortalama varyansın (AOV), o yapı ile diğer yapılar arasında bulunan korelasyon katsayılarının karesinden büyük olması varsayımına dayanmaktadır. Tablo 3'te verilen korelasyon değerleri karesi ve AOV değerlerine göre bütün faktörler için ayrışma geçerliliğinin varlığından söz edilebilmektedir. 


\section{Araştırma Bulguları}

Bu çalışmada belirlenen araştırma hipotezlerinin testleri kapsamında, ankete katılan Akdeniz Üniversitesi akademik personelinin \%53'ü (159) erkek ve \%47'si (141) kadındır. Yaş grupları olarak ankete katılan Akdeniz Üniversitesi akademik personelinin \%42,3'ü (127) 31-40 yaş arasında, \%23,7'si (71) 41-49 yaş arasında, $\% 23,3$ 'ü (70) 30 yaş ve altında ve son olarak \%10,7'si (32) 50 yaş ve üzerindedir. Ankete katılan akademik personelin unvan dağılımı olarak \%26,7'si (80) Araştırma Görevlisi, \%26,3'ü (79) Yardımcı Doçent Doktor, \%22,7'si (68) Öğretim Görevlisi, \%14,3'ü (43) Doçent Doktor ve \%10'u (30) Profesör Doktordur. Ankete katılan akademik personelin çevrimiçi alışveriş geçmişi incelendiğinde, \%45,2'si (135) 1-5 yıldır, \%44,4'ü (133) 6-10 yıldır ve son olarak \%10,4'ü (31) 11 yıl ve üzerinde çevrimiçi alışveriş yapmaktadır. Yıllık seyahat sıklığı açısından ankete katılan Akdeniz Üniversitesi akademik personelinin, \%31,5'i (94) 4-6 kere, \%28,9'u (86) 1-3 kere, $\% 22,2$ 'si (66) 7-10 kere ve son olarak \%17,4'ü (52) 11 kere ve üzerinde seyahat etmektedir.

Araştırma bulguları kapsamında müşteri memnuniyeti, e-hizmet kalitesi ve müşteri sadakati arasında, anlamlı bir neden-sonuç ilişkisi olup olmadığını anlamak amacıyla çoklu regresyon analizinden faydalanılmıştır. $\mathrm{Bu}$ maksat ile müşteri memnuniyeti ölçeği ortalaması ve e-hizmet kalitesi ölçeği ortalaması bağımsız değişken, müşteri sadakati ölçeği ortalaması bağımlı değişken olarak ele alınmıştır. Yapılan çoklu regresyon analizi sonuçları Tablo 4'te gösterilmiştir.

Tablo 4: Müşteri Memnuniyeti, E-Hizmet Kalitesi ve Müşteri Sadakati İlişkisi

\begin{tabular}{|l|c|c|c|}
\hline & $\beta$ Katsayısı & $t$-değeri & $p$ \\
\hline (Sabit Değer) & $-0,215$ & $-1,327$ & 0,185 \\
\hline Müşteri Memnuniyeti & 0,709 & 16,302 &, $000^{* *}$ \\
\hline E-hizmet kalitesi & 0,190 & 4,372 &, $000^{* *}$ \\
\hline $\mathrm{R}^{2}=0,734 \mathrm{~F}=409,875 \mathrm{p}=, 000^{* \star}{ }^{* *} \mathrm{p}<0,01$ &
\end{tabular}

Tablo 4'te yer alan regresyon modeli anlamlıdır $(F=409,87 p=, 000)$. Analiz sonuçları müşteri memnuniyetinin, müşteri sadakatini etkileyen önemli bir boyut olduğu göstermektedir. $(\beta=0,709)$. Bunun yanında e-hizmet kalitesi algısı ile sadakat arasındaki ilişki, göreceli olarak daha düşüktür $(\beta=0,190)$. Bu bulgu, alanyazında yapılmış birçok çalışma ile örtüşmektedir. Örneğin Parasuraman ve diğ (2005), yapmış oldukları çalışma ile müşteri memnuniyetinin, müşteri sadakatini etkileyen önemli bir boyut olduğunu ortaya çıkarmıştır. Aynı şekilde Bauer ve diğ. (2006), yapmış olduğu çalışma ile müşteri sadakatı yaratmak için, müşteri memnuniyetinin önemine dikkat çekmiştir. Yapılan çoklu regresyon analizi sonuçlarına göre, "H1: Elektronik hizmet kalitesi ile müşteri memnuniyeti arasında pozitif yönlü bir ilişki vardır.", "H2: Elektronik hizmet kalitesi ile müşteri sadakati arasında pozitif yönlü bir ilişki vardır." ve "H3: Müşteri memnuniyeti ve müşteri sadakati arasında pozitif yönlü bir ilişki vardır." hipotezleri kabul edilmiştir.

Algılanan e-hizmet kalitesi ile müşteri memnuniyeti arasındaki ilişkiyi daha detaylı inceleyebilmek için, e-hizmet kalitesi ölçeği boyutları bağımsız değişken, müşteri memnuniyeti ölçeği ortalaması bağımlı değişken olarak ele alınmıştır ve çoklu regresyon analizi yapılmıştır. Yapılan çoklu regresyon analizi sonuçları Tablo 5'de verilmiştir. 
Tablo 5: Müşteri Memnuniyeti ve E-Hizmet Kalitesi İlişkisi

\begin{tabular}{|l|c|c|c|}
\hline Faktörler & $\beta$ Katsayısı & $t$-değeri & $p$ \\
\hline (Sabit Değer) & 4,204 & 156,950 &, $000^{* *}$ \\
\hline Web Site İşlevselliği & 0,409 & 10,615 &, $000^{* *}$ \\
\hline Müşteri Ilişkileri & 0,357 & 9,269 &, $000^{* *}$ \\
\hline Isteklerin Yerine Getirilmesi ve Duyarlıık & 0,325 & 8,440 &, $000^{* *}$ \\
\hline Emniyet ve Güvenlik & 0,257 & 6,672 &, $000^{* *}$ \\
\hline Enformasyon Kalitesi ve İçerik & 0,242 & 6,268 &, $000^{* *}$ \\
\hline Görünüş ve Sunum & 0,199 & 5,165 &, $000^{* *}$ \\
\hline
\end{tabular}

$R^{2}=0,565 F=63,383 p=, 000^{\star *} \quad{ }^{* *} p<0,01$

Tablo 5'de yer alan regresyon modeli anlamlıdır $(F=63,383 p=, 000)$. Tablo'da bulunan standardize edilmiş $\beta$ katsayıları incelendiğinde, e-hizmet kalitesinin "Web Site İşlevselliği" boyutunun memnuniyete etki eden en önemli boyut olduğu, "Görünüş ve Sunum" boyutunun ise memnuniyete etki eden en düşük boyut olduğu görülmektedir $(\beta=0,199)$. Benzer şekilde, algılanan e-hizmet kalitesi ile müşteri sadakati arasındaki ilişkiyi daha detaylı inceleyebilmek için e-hizmet kalitesi ölçeği boyutları bağımsız değişken, müşteri sadakati ölçeği ortalaması ise bağımlı değişken olarak ele alınmış ve çoklu regresyon analizi yapılmıştır. Yapılan çoklu regresyon analizi sonuçları Tablo 6'da verilmiştir.

Tablo 6: Müşteri Sadakati ve E-Hizmet Kalitesi İlişkisi

\begin{tabular}{|l|c|c|c|}
\hline Faktörler & $\beta$ Katsayısı & $t$-değeri & $p$ \\
\hline (Sabit Değer) & 4,083 & 130,807 &, $000^{* *}$ \\
\hline Web Site İşlevselliği & 0,360 & 8,898 &, $000^{* *}$ \\
\hline Müşteri Ilişkileri & 0,356 & 8,797 &, $000^{* *}$ \\
\hline İsteklerin Yerine Getirilmesi ve Duyarlıık & 0,347 & 8,576 &, $000^{* *}$ \\
\hline Enformasyon Kalitesi ve İçerik & 0,225 & 5,550 &, $000^{* *}$ \\
\hline Görünüş ve Sunum & 0,223 & 5,509 &, $000^{* *}$ \\
\hline Emniyet ve Güvenlik & 0,209 & 5,163 &, $000^{* *}$ \\
\hline
\end{tabular}

$\mathrm{R}^{2}=0,520 \mathrm{~F}=52,986 \mathrm{p}=, 000^{\star *} \quad{ }^{* *} \mathrm{p}<0,01$

Tablo 6'da yer alan regresyon modeli anlamlıdır $(F=52,986 p=, 000)$. Tablo'da bulunan standardize edilmiş $\beta$ katsayıları incelendiğinde, benzer biçimde e-hizmet kalitesinin "Web Site İşlevselliği" boyutunun, memnuniyet algısında olduğu gibi, sadakate etki eden en önemli boyut olduğu saptanmıştır $(\beta=0,360)$. "Emniyet ve Güvenlik" boyutunun ise sadakate etki eden en düşük boyut olduğu görülmektedir $(\beta=0,209)$. Yapılan değerlendirmede e-hizmet kalitesi boyutlarının, müşterilerin memnuniyet ve sadakat algısındaki etki düzeylerinin farklı olduğu görülmektedir.

\section{Tartışma, Sonuç ve Öneriler}

Analiz sonuçları, "Web Site Iş̧levselliği", "Müşteri Ilişskileri" ve "İsteklerin Yerine Getirilmesi ve Duyarlılı" boyutlarının, müşterilerin web tabanlı seyahat aracılarının sistemlerine yönelik memnuniyet ve sadakat algılarında, önem derecelerine göre ilk üç sırayı aldığını göstermektedir. "Emniyet ve Güvenlik" boyutu, müşteri memnuniyeti için 
önem derecesine göre dördüncü sırada olmasına rağmen bu boyut, sadakat algısında son sırayı almaktadır. Sadık müşterilerin, web tabanlı aracılardan hizmet satın alma hususunda sisteme olan güven düzeyleri zamanla yükselmeye başlamakta ve bu durum bu boyutun, sadakat algısındaki önem düzeyini düşürmektedir. Sadık müşteriler için zamanla "Enformasyon Kalitesi ve Içerik" boyutunun, sadakat algısında daha önemli olmaya başladığı görülmektedir. Aynı şekilde "Görünüş ve Sunum" boyutu, müşteri memnuniyetine oranla, müşteri sadakatinde daha önemli bir boyut olarak dikkat çekmektedir. Analiz sonuçları, müşteri memnuniyeti ve müşteri sadakatini etkileyen hizmet kalitesi boyutlarının farklılaştığını göstermektedir. İşletmeler, sadık müşterilerin e-hizmet kalitesi algılarını sürekli ölçerek, önem verdikleri önceliklere göre ürün ve hizmetlerinde iyileştirmeler ve farklılaştırmalar yapmalıdır.

"Web Site Işslevselliği" boyutunun, memnuniyete ve sadakate etki eden en önemli boyut olduğu sonucuna ulaşılmıştır. Bu bulgu, alanyazında yapılmış birçok çalışma ile benzerlik göstermektedir. Örneğin Bauer ve diğ. (2006), web site işlevselliğinin algılanan e-hizmet kalitesini etkileyen çok önemli bir boyut olduğunu ortaya çıkarmıştır. Çevrimiçi tüketici sayılarının gün geçtikçe artması, web sitelerinin işlevsel olması gerekliliğine de beraberinde getirmektedir. Özellikle turizm ve seyahat alanında faaliyet gösteren çevrimiçi işletmelerin web siteleri bilgilendirici, interaktif ve çekici olmak durumundadır (Law ve diğ., 2008). Çevrimiçi alışverişte memnun müşteriler yaratmak ve satın alma eylemini keyifli bir hale getirmek için, web sitelerinin mutlaka işlevsel şekilde tasarlanması gerekmektedir. Web site işlevselliğinin, müşteri memnuniyeti üzerindeki etkisini anlamlı kılan bazı diğer sebepler de bulunmaktadır (Tsang ve diğ., 2010). Öncelikle işlevsel olan bir web tabanlı seyahat aracısı sistemi, kullanıcılarına her konuda, yapmak istedikleri şeyleri yapmaya fırsat vermektedir. Ayrıca, satın alınmak istenen tatil ve seyahat hakkında iyi şekilde işleyen bir bilgi sistemi veya fiyat karşılaştırma olanaklarının bulunması, kullanıcılara fayda sağlamaktadır. Sistemi işlevsel olan web tabanlı seyahat aracıları, tartışmasız sadık müşteriler kazanacaktır.

Müşteri memnuniyetini ve müşteri sadakatini etkileyen bir diğer önemli boyut "Müşteri Illişkileri" boyutudur. Kullanıcılarına iyi bir müşteri ilişkileri hizmeti sunan web tabanlı seyahat aracıları, kuşkusuz memnun müşteriler yaratacaktır. Bu durum olumlu ağızdan ağıza iletişimi de artırmaktadır. Yaratılan bu olumlu ağızdan ağıza iletişim, hem mevcut kullanıcıları sisteme bağlarken, hem de yeni kullanıcılar yaratacaktır. Bu sebeple müşteri ilişkileri boyutu, gerek müşteri memnuniyeti, gerekse müşteri sadakati oluşturulması açısından son derece önemlidir. Liao ve diğ. (2001), yapmış oldukları çalışma ile birlikte ayrıca, çevrimiçi işletme yöneticilerinin mevcut e-hizmet kalitesini sürekli kılmak için, müşteri ilişkileri sisteminin mutlaka periyodik olarak denetlenmesi gerekliliğini ortaya koymuştur.

Müşteri memnuniyetini ve müşteri sadakatini etkileyen bir diğer boyut "İsteklerin Yerine Getirilmesi ve Duyarlılı" boyutudur. Gerek geleneksel işletmelerde olsun, gerekse çevrimiçi işletmelerde olsun her müşteri, satın alacağı ürün veya hizmet koşullarında belirtilen bütün şartlara uyulmasını istemektedir. Bu sebeple, web tabanlı seyahat aracıları mutlaka müşteri istek, talep ve intiyaçlarına zamanında ve yeteri kadar cevap verebilmelidir. Bu durum en basit hali ile işletmelere memnun müşteriler kazandıracaktır. Memnun müşterilerin, sadık ve tekrarlayan müşterilere dönüşmesi ise kaçınılmazdır. Çalışmada bu boyutun, müşteri memnuniyeti ve müşteri sadakatini etkileyen önemli bir boyut olması sonucuna karşın, Tsang ve diğ. (2010) yapmış olduğu çalışmada bu boyutun, müşteri memnuniyetine ve müşteri sadakatine etkisi anlamlı bulunamamıştır. Bu farklılık, belki de araştırmaların yapıldığı kültürden kaynaklanmaktadır. Tsang ve diğ. (2010), çalışmalarını Hong Kong'da yapmıştır. Tsang ve diğ. (2010) göre Hong Kong, gerek internet teknolojileri olsun, gerek 
çevrimiçi işletmeler konusunda olsun, son derece gelişmiş bir ülkedir. Hong Kong'da faaliyet gösteren web tabanlı seyahat aracıları, çok nadir bir şekilde müşteri istek, talep ve intiyaçları konusunda hata yapmaktadır. Bu sebeple kullanıcılar bu boyutu, web tabanlı seyahat aracılarına duyulan memnuniyeti etkileyen bir boyut olarak görmemektedir; ancak Türkiye'de web tabanlı seyahat aracılarına henüz tam olarak güven oluşamadığı için, bu boyut, müşteri memnuniyetini ve müşteri sadakatini etkileyen önemli bir boyut olarak karşımıza çıkmaktadır.

Müşteri memnuniyetini etkiyen bir diğer önemli boyut "Emniyet ve Güvenlik" boyutudur. Ancak bu boyut, müşteri sadakatini etkileyen en son boyuttur. Emniyet ve güvenlik boyutunun, müşteri memnuniyeti ve müşteri sadakati üzerinde görece daha az etkiye sahip olması, Wolfinbarger ve Gilly (2003) tarafından yapılan çalışmanın bulguları ile benzerlik göstermektedir. Wolfinbarger ve Gilly 'ye göre kullanıcılar, çevrimiçi işletmelere yönelik emniyet ve güvenlik boyutunu, web sitelerin vermiş oldukları genel intiba ile birlikte değerlendirir. Çevrimiçi işletmelerin web sitelerinin profesyonel görünüşü veya işlevsel olması, kullanıcıların emniyet ve güvenlik boyutuna ilişkin algılarını da etkilemektedir. Şüphesiz ki kullanıcılar, çevrimiçi ortamda faaliyet gösteren işletmelerden, gerek mal veya hizmet satın alırken, gerek kişisel bilgilerini sistem ile paylaşırken kendilerini güvende hissetmek ister. Basit bir şekilde, kendilerini web tabanlı seyahat aracıları sistemi tarafından korunuyor hisseden kullanıcılar, o işletmeye karşı güven duyacaktır. Duyulan bu güven, memnun müşteriler yaratmak adına son derece önemlidir. Bu bulgu, emniyet ve güvenlik boyutunun hem e-hizmet kalitesini etkilediği, hem de müşteri memnuniyeti ve müşteri sadakati yaratmak açısından önemli olduğu sonucunu ortaya çıkarmaktadır.

Müşteri memnuniyetini ve müşteri sadakatini etkileyen bir diğer önemli boyut "Enformasyon Kalitesi ve İçerik" boyutudur. Bu boyut, satın alma davranışı üzerinde büyük etkiye sahiptir. Kullanıcılar, bir web tabanlı seyahat aracısını kullanırken, planladıkları tatil veya seyahat hakkında derinlemesine bilgi almak intiyacı hisseder. Eğer kullanıcılar, ilgili web tabanlı seyahat aracıları sisteminde planladıkları tatil veya seyahat hakkında kaliteli bilgi ya da içerik bulamazlarsa, bu bilgi arama süreci satın almaya dönüşmeyecek ve bu durum, ilgili web tabanlı seyahat aracıları sistemine yönelik memnun olmamış müşteriler yaratacaktır. Bu sebeple bu boyut, elde bulunan mevcut kullanıcıları tutmak ve yeni kullanıcılar kazanmak adına son derece önemlidir. Sarı ve Kozak (2005), yapmış oldukları çalışma ile birlikte çevrimiçi işletmelerin web sitelerinde sunulan ürünler ve hizmetler hakkında bilgi verilmesinin, bilgi elde etmek için aracıların ortadan kaldırılarak, daha bağımsız bir bilgi akışının sağlanmasının, alternatif ürün ve hizmetlerin karşılaştırılmasına olanak verilmesinin, internet aracılığı ile seyahate çıkma arzusunda bulunan çevrimiçi müşteriler için son derece önemli olduğu sonucuna varmıştır.

Müşteri memnuniyetini ve müşteri sadakatini etkileyen bir diğer boyut "Görünüş ve Sunum" boyutudur. Bu boyutun müşteri memnuniyetine etki eden son boyut olması, alanyazında yapılan bazı çalışmalar ile benzerlik göstermektedir. Örneğin Zhang ve diğ. (1999), yapmış oldukları çalışmada, web sayfalarının görünüşlerinin, müşteri memnuniyeti yaratmak için gerekli; ancak yeterli olmadığını belirtmektedir. Memnun müşteri potansiyeli yaratmak, aslında bir çok web sayfa tasarımcısının ulaşmak istediği hedeflerden biridir. Elbette kullanıcılar, görünüş olarak memnun kaldıkları web tabanlı seyahat aracılarının sistemlerinde daha uzun süre zaman harcayacak, ilerleyen zamanlarda sistemi tekrar ziyaret edecek ve çevresindeki kullanıcılara, sistem hakkında olumlu görüşlerini bildirecektir. 
Sonuç olarak e-hizmet kalitesi, memnuniyet ve sadakat arasında pozitif yönde bir iliş̧inin olduğu saptanmıştır. Ayrıca e-hizmet kalitesini oluşturan her bir boyutun, memnuniyet ve sadakat üzerinde farklı önem derecelerinde etkisinin olduğu görülmektedir. Bu çalışmada, nicel yöntem kullanılarak sözü edilen üç değişken arasındaki ilişkinin analiz edilmesi amaçlanmıştır. Ancak, sadık müşteriler için e-hizmet kalitesinin bazı boyutlarının önem derecelerinin neden, nasıl düştüğünün veya yükseldiğinin araştırılması, turizm ürün ve hizmet sağlayıcıları için önemli ipuçları verebilir. Bu bağlamda, konunun daha derinlemesine analiz edilebilmesi için nitel yöntemlere dayanan çalışmaların da yapııması ihtiyacı ön plana çıkmaktadır.

\section{Kaynakça}

Avcıkurt, C. ve Köroğlu, Ö. (2006). Termal Otel İşletmelerinde Müşteri Sadakatini Artıran Nitelikleri Belirlemeye Yönelik Bir Alan Araştırması, Seyahat ve Otel Işletmeciliği Dergisi, 5-16.

Bauer, H. H., Falk, T. ve Hammerschmidt, M. (2006). eTransQual: A Transaction Process-Based Approach for Capturing Service Quality in Online Shopping, Journal of Business Research, 866-875.

Bressolles, G., Durrieu, F. ve Senecal, S. (2014). A Consumer Typology Based on EService Quality and E-Satisfaction, Journal of Retailing and Consumer Services, 889-896.

Buhalis, D. (2003) eTourism: Information Technology for Strategic Tourism Management. London: Prentice Hall.

Büyüköztürk, Ş. (2011). Sosyal Bilimler İçin Veri Analizi El Kitabı. Ankara: Pegem.

Castaneda, J. A. (2011). Relationship Between Customer Satisfaction and Loyalty on the Internet, Journal of Business \& Psychology, 371-383.

Chang, H., Lee, C.-H. ve Lai, C.-Y. (2012). E-Service quality and relationship quality on dealer satisfaction: Channel power as a moderator, Total Quality Management, 855-873.

Cheng, B.-L. ve Rashid, M. A. (2013). Service Quality and the Mediating Effect of Corporate Image on the Relationship between Customer Satisfaction and Customer Loyalty in the Malaysian Hotel Industry, International Journal of Business, 99-112.

Churchill, G. A. (1979). A Paradigm For Developing Better Measures of marketing Constructs, Journal of Marketing Research, 64-73.

Çatı, K. ve Koçoğlu, C. M. (2008). Müşteri Sadakati ile Müşteri Tatmini Arasındaki İlişkiyi Belirlemeye Yönelik Bir Araştırma, Selçuk Üniversitesi Sosyal Bilimler Enstitüsü Dergisi, 167-188.

Çelik, H. ve Başaran, B. (2008). Bireysel Müşteriler Tarafından Algılanan Elektronik Hizmet Kalitesi, Anadolu Üniversitesi Sosyal Bilimler Dergisi, 129-152.

Flavian, C., Guinaliu, M. ve Gurrea, R. (2006). The Role Played by Perceived Usability, Satisfaction and Consumer Trust on Website Loyalty, Information Management, $1-14$

Fornell, C. ve Larcker, D. F. (1981). Evaluating Structural Equation Models with Unobservable Variables and Measurement Error, Journal of Marketing Research, 39-50.

Hair, J., Ronald, L., Rolph, E. ve William, B. (1998). Multivariate Data Analysis, 5th Edition, USA: Prentice Hall.

Ho, C. I. ve Lee, Y. L. (2007). The Development of an E-Travel Service Quality Scale, Tourism Management, 1434-1449.

Huang, W. Y. ve Dubinsky, A. J. (2014). Measuring Customer Pre-Purchase Satisfaction in a Retail Setting, The Service Industries Journal, 212-229. 
Kline, R. B. (2005). Principles and Practice of Structural Equation Modeling (2nd Edition ed.), New York: The Guilford Press.

Ladhari, R. (2010). Developing E-Service Quality Scales: A Literature Review, Journal of Retailing and Consumer Services, 464-477.

Law, R., Qi, S. ve Leung, B. (2008). Perception of Functionality and Usability on Travel Websites: The Case of Chinese Travelers, Asia Pacific Journal of Tourism Research, 435-445.

Liao, C.-H., Yen, H. ve Li, E. (2011). The Effect of Channel Quality Inconsistency on the Association Between E-Service Quality and Customer Relationships, Internet Research, 458-478.

Luo, S.-F. ve Lee, T.-Z. (2011). The Influence of Trust And Usefulness On Customer Perceptıons of E-Service Quality, Social Behavior And Personality, 825-838.

Marimon, F., Yaya, L. P. ve Fa, M. C. (2012). Impact of E-Quality and Service Recovery on Loyalty a Study of E-Banking in Spain, Total Quality Management, 769-787.

Nakip, M. (2003). Pazarlama Araştırmaları: Teknikler ve Uygulamalar, Ankara: Seçkin Kitapevi.

Nunnally, J. C. (1978). Psychometric Theory, New York: Mcgraw-Hill.

Oliveira, P., Roth, A. V. ve Gilland, W. (2002). Achieving Competitive Capabilities in EServices, Technological Forecasting \& Social Change, 721-739.

Oliver, R. L. (1980). A Cognitive Model of the Antecedents and Consequence of Satisfaction Decisions, Journal of Marketing Research, 460-470.

Osman, Z. ve Sentosa, I. (2013). A Study of Mediating Effect of Trust on Customer Satisfaction and Customer Loyalty Relationship in Malaysian Rural Tourism, European Journal of Tourism Research, 192-206.

Özdamar, K. (2004). Paket Programlar ile Istatistiksel Veri Analizi, Eskişehir: Kaan Kitabevi.

Özdemir, B., Aksu, A. A., Ehtiyar, V. R., Çizel B., Çizel R. ve İçigen E. (2012). Relationships Among Tourists Profile Satisfaction and Destination Loyalty: Examining Emprical Evidences in Antalya Region of Turkey, Journal of Hospitality Marketing and Management, 506-540.

Papaioannou, E., Sarmaniotis, C., Assimakopoulos, C. ve Georgiadis, C. K. (2013). Investigating Customer Satisfaction Dimensions With Service Quality of Online Auctions: An Empirical Investigation of E-Bay, Inf Syst E-Bus Manage, 313-330.

Parasuraman, A., Zeithaml, V. A. ve Berry, L. L. (1988). SERVQUAL: A Multiple-Item Scale for Measuring Consumer Perceptions of Service Quality, Journal of Retailing, 12-39.

Parasuraman, A., Zeithaml, V. A. ve Malhotra, A. (2005). A Multiple-Item Scale for Assessing Electronic Service Quality, Journal of Service Research, 213-233.

Pearson, A., Tadisina, S. ve Griffin, C. (2012). The Role of E-Service Quality and Information Quality in Creating Perceived Value: Antecedents to Web Site Loyalty, Information Systems Management, 201-215.

Ruyter, K., Wetzels, M. ve Kleijnen, M. (2001). Customer Adoption of E-Service: An Experimental Study, International Journal of Service Industry Management, 184207.

Santos, J. (2003). E-Service Quality: A Model of Virtual Service Quality Dimensions, Managing Service Quality, 233-246.

Sarı, Y. ve Kozak, M. (2005). Turizm Pazarlamasına İnternetin Etkisi: Destinasyon Web Siteleri İçin Bir Model Önerisi, Akdeniz I.I.B.F. Dergisi, 248-271.

Schumacker, R. E. (2004). Rasch Measurement: The Dichotomous Model, Introduction to Rasch measurement., 226-253. 
Shu-Fang, L. ve Tzai-Zang, L. (2011). The Influence of Trust and Usefulness on Customer Perceptıons of E-Service Quality, Social Behavior And Personality, 825-838.

Şenel, B., Şenel, M. ve Gümüştekin, G. E. (2012). E-Hizmet Kalitesine Göre Sanal Alışveriş Sitelerinin Değerlendirilmesi, Dumlupınar Üniversitesi Sosyal Bilimler Dergisi, 85-100.

Tsang, N. K., Lai, M. T. ve Law, R. (2010). Measuring E-Service Quality for Online Travel Agencies, Journal of Travel \& Tourism Marketing, 306-323.

Wolfinbarger, M. ve Gilly, M. C. (2003). ETailQ: Dimensionalizing, Measuring and Predicting Retail Quality, Journal of Retailing, 183-198.

Yang, H. E., Wu, C. C. ve Wang, K. C. (2009). An Empirical Analysis of Online Game Service Satisfaction and Loyalty, Expert Systems with Applications, 1816-1825.

Zhang, P., Von Dran, G. M., Small, R. V. ve Barcellos, S. (1999). Websites that Satisfy Users: A Theoretical Framework for Web User Interface Design and Evaluation. Proceedings of the 32nd Hawaii International Conference on System Science, Washington: IEEE Computer Society. 